\title{
Response of Tropical Maize to Supplemental Irrigation Strategies
}

\section{Priscila Ponciana Gomes da Silva ${ }^{1}$, Camilo de Lelis Teixeira de Andrade ${ }^{2}$, João Carlos Ferreira Borges Junior ${ }^{3}$, Bruna Gomes Magalhaes ${ }^{4}$, Bruno Ferreira de Melo ${ }^{5}$, Axel Garcia y Garcia $^{6}$}

${ }^{1}$ Undergrad Fellow, Fed. Univ. of Sao Joao del Rei, prigomes18@hotmail.com

${ }^{2}$ Researcher, Embrapa Maize and Sorghum, camilo.andrade@embrapa.br

${ }^{3}$ Assistant Professor, Fed. Univ. of Sao Joao del Rei, jcborges@ufsj.edu.br

${ }^{4}$ MSc Student, Fed. Univ. of Sao Joao del Rei, bruna@setelagoas.com.br

${ }^{5}$ Undergrad Fellow, UNIFEMM, brunoferreiramelo@hotmail.com

${ }^{6}$ Assistant Professor, University of Minnesota Cropping Systems, Department of Agronomy and Plant Genetics, Lamberton, MN, axel@umn.edu

Written for presentation at the

2016 ASABE Annual International Meeting

$$
\begin{gathered}
\text { Sponsored by ASABE } \\
\text { Orlando, Florida } \\
\text { July 17-20, } 2016
\end{gathered}
$$

Abstract. Water is one of the most important factors influencing crop production in rainfed cropping systems. In tropical regions, supplemental irrigation reduces the risk of yield losses associated to water deficit due to insufficient rainfall. Water deficit in regions with irregularities in rainfall may be overcome with the use of supplemental irrigation, a technique based on the application of water at amounts below the crop's evapotranspiration (ETC). We investigated the potential of supplemental irrigation as a strategy to increase yield of maize grown under tropical conditions. We used the CSM-CERES-Maize model of the Decision Support System for Agrotechnology Transfer (DSSAT) to simulate irrigation strategies of maize in six counties in the state of Minas Gerais, Brazil. Our results indicate significant differences on simulated crop yield in response to supplemental irrigation. As a consequence, water productivity was improved with reductions of $10 \%$ and $15 \%$ of full irrigation depths in one of the six counties while in two the water productivity was higher when full irrigation was applied.

Keywords. Water productivity; Deficit irrigation; DSSAT; Zea mays L.

\footnotetext{
The authors are solely responsible for the content of this meeting presentation. The presentation does not necessarily reflect the official position of the American Society of Agricultural and Biological Engineers (ASABE), and its printing and distribution does not constitute an endorsement of views which may be expressed. Meeting presentations are not subject to the formal peer review process by ASABE editorial committees; therefore, they are not to be presented as refereed publications. Citation of this work should state that it is from an ASABE meeting paper. EXAMPLE: Author's Last Name, Initials. 2016. Title of Presentation. ASABE Paper No. ---. St. Joseph, Mich.: ASABE. For information about securing permission to reprint or reproduce a meeting presentation, please contact ASABE at rutter@asabe.org or 269-932-7004 (2950 Niles Road, St. Joseph, MI 49085-9659 USA).
} 


\section{Introduction}

Maize is one of the most important cereals as a source of energy for humans and animals (FAO, 2015). Brazil is the world third largest producer of maize. In the Southeast region of the country, Minas Gerais is the largest maize producer state, accounting for $8.1 \%$ of the national production (IBGE, 2015). However, according to the survey of the Brazilian National Company for Food Supply (Conab, 2015), maize production in the state of Minas Gerais during the $2014 / 2015$ crop season was reduced by around $5 \%$ as compared to the previous growing season (2013/2014), from 5.74 million tons to 5.46 million tons. This maize yield reduction is associated with two factors: 1 - the rainfall scarcity and temperature raise that occurred in the last three years; 2 - the maize cropping systems that is predominantly carried during the rainy season has move to the offseason, which has a lower yield potential (Shioga et al. 2004).

Maize belongs to the group of plants with $\mathrm{C} 4$ photosynthetic metabolism and is characterized by high yield potential (Bergamaschi, 2004). However, abiotic factors with temperature, precipitation, solar radiation even occurring in the early stages, can affect yield (Castro \& Garcia, 1996). Water stress due to lack of rainfall is the main factor linked to variations on yield of most crops (Nied et al. 2005). The average probability of yield break due to water deficit is approximately 50\% (Wagner et al. 2013).

Supplemental irrigation is a management strategy of water resources to minimize risks associated to limited water in crop production. A variation of this approach is deficit irrigation (Frizzone, 2007), which consists on applying water at amounts below the requirements to satisfy the crop water needs (Kang et al. 2000). In general, the deficit is imposed in periods when the plant is less sensitive to the effects of water stress (Lima, 2012). The main objective of this practice is to increase the water productivity of crops while eliminating irrigations with little to no reduction of yield (Kirda, 2002). The adoption of deficit irrigation can maximize the water productivity since a small reduction in yield may provide as much as that from full irrigation (Geerts \& Raes, 2009). According to English (1990), in areas with water scarcity, maximizing water productivity can be economically more profitable than maximizing yield. Increased water productivity in agriculture plays an important rule to alleviate the competition for scarce resources, to reduce pressure to environment and to ensure food security (Molden et al. 2003).

Models can assist in evaluating the response of crops to irrigation management strategies based on soil-water availability and soil depth, irrigation system efficiency and irrigation requirements, among others. The Decision Support System for Agrotechnology Transfer (DSSAT) is an integrated tool, applicable to support management decisions and to estimate crop yield, among other purposes (Jones et al. 2003). The CSM-CERES-Maize (Jones \& Kiniry, 1986), which is part of DSSAT, allows for the evaluation of different management options.

The main objective of this study was to assess the response of maize grown to supplemental irrigation in a tropical region. Specific objectives were to a) simulate different supplemental irrigation strategies and determine the effect deficit irrigation on yield of maize.

\section{Material and methods}

The study was based on the simulation of yield and irrigation water productivity of maize for different scenarios of supplemental irrigation with CSM-CERES-Maize model of DSSAT v4.6.1 (Hoogenboom et al. 2014). Preliminary simulations were performed for the single-cross hybrid DKB390PRO to identify the sowing date that provided the highest maize yield under irrigated conditions in six locations in the state of Minas Gerais: Janauba, Lavras, Patos de Minas, Paracatu, Sete Lagoas and Uberaba. Characterization of the soil profile in representative farms of the six counties was performed and samples collect at 0-0.05 m, 0.05-0.20 m, 0.20-0.40 m, 0.40-0.70 and 0,70 to $1.00 \mathrm{~m}$ were analyzed and used as input data to the model. Results of available water (AW) and water holding capacity (WHC) for the six locations are presented in Table 1.

The weather data used as input to the model were daily maximum and minimum temperature, rainfall and solar radiation derived from sunshine hours. The data were obtained from the National Institute of Meteorology (INMET) for the 1981-2013 period, totaling 33 years. The Weatherman tool (Pickering et al. 1994) of the DSSAT was used for quality control, for filling data gaps for periods of 7 days or less, and for the estimation of the solar radiation from sunshine hours, a procedure that uses the approach of Angstrom-Prescott (Angstrom, 1924; Prescott, 1940). In few instances, the Angstrom-Prescott coefficients were standardized as 0.25 and 0.50 , respectively, as recommended by Allen et al. (1998). 
Table 1: Available water (AW) and water holding capacity (WHC) of representative soils at six locations in the state of Minas Gerais, Brazil.

\begin{tabular}{|c|c|c|c|}
\hline Locations & Layer (m) & $\mathrm{AW}\left(\mathrm{m} \mathrm{m}^{-1}\right)$ & $\mathrm{WHC}(\mathrm{mm})$ \\
\hline \multirow{5}{*}{ Janauba } & 0.05 & 0.158 & 7.90 \\
\hline & 0.20 & 0.103 & 15.45 \\
\hline & 0.40 & 0.108 & 21.60 \\
\hline & 0.50 & 0.114 & 11.40 \\
\hline & $0-0.50$ & & 56.35 \\
\hline \multirow{5}{*}{ Lavras } & 0.05 & 0.158 & 7.90 \\
\hline & 0.20 & 0.114 & 22.80 \\
\hline & 0.40 & 0.125 & 50.00 \\
\hline & 0.50 & 0.125 & 62.50 \\
\hline & $0-0.50$ & & 142.95 \\
\hline \multirow{5}{*}{ Paracatu } & 0.05 & 0.109 & 5.50 \\
\hline & 0.20 & 0.108 & 21.60 \\
\hline & 0.40 & 0.109 & 43.60 \\
\hline & 0.50 & 0.111 & 55.50 \\
\hline & $0-0.50$ & & 138.85 \\
\hline \multirow{5}{*}{ Patos de Minas } & 0.05 & 0.152 & 7.60 \\
\hline & 0.20 & 0.145 & 29.00 \\
\hline & 0.40 & 0.094 & 37.60 \\
\hline & 0.50 & 0.099 & 49.50 \\
\hline & $0-0.50$ & & 123.70 \\
\hline \multirow{5}{*}{ Sete Lagoas } & 0.05 & 0.109 & 5.50 \\
\hline & 0.20 & 0.113 & 22.60 \\
\hline & 0.40 & 0.125 & 50.00 \\
\hline & 0.50 & 0.125 & 62.50 \\
\hline & $0-0.50$ & & 140.55 \\
\hline \multirow{5}{*}{ Uberaba } & 0.05 & 0.144 & 7.20 \\
\hline & 0.20 & 0.146 & 29.20 \\
\hline & 0.40 & 0.128 & 51.20 \\
\hline & 0.50 & 0.133 & 66.60 \\
\hline & $0-0.50$ & & 154.10 \\
\hline
\end{tabular}

The simulations assumed $2000 \mathrm{~kg} \mathrm{ha}^{-1}$ of residue from the previous crop (brachiaria) with $1 \%$ nitrogen in all locations. Maize crop sown to a depth of $0.05 \mathrm{~m}$, with a row spacing of $0.5 \mathrm{~m}$ and a stand of 68,000 plants ha $^{-1}$. The beginning of all simulations was set one month before the date of sowing in order to allow for the model to estimate more realistically the soil-water content. Fertilization consisted of $40 \mathrm{~kg} \mathrm{ha}^{-1}$ of nitrogen in the form of mono-ammonium phosphate (MAP) plus $150 \mathrm{~kg} \mathrm{ha}^{-1}$ of nitrogen in the form of urea, side-dressed 25 days after 
sowing.

To simulate supplemental irrigation management strategies, the experimental analysis tool of the model was used. As a first step, it was created for each year of each county an experimental file, totaling 198 files, which were used to simulate maize full irrigation management. The irrigation was set as a sprinkler irrigation system with $100 \%$ efficiency. The irrigation was triggered when the soil-water content, in the top $0.30 \mathrm{~m}$ layer dropped to $50 \%$ of the total soil-water availability. In a second step, for each year and location, irrigation strategies consisting on full irrigation (I00) and 5\% (I05), 10\% (I10), 15\% (I15), 20\% (I20) and 25\% (I25) reduction of I00 were set. Simulated yield was corrected to $13 \%$ moisture content. The irrigation water productivity of maize was determined by the ratio between the yield, correct for $13 \%$ moisture in $\mathrm{kg} \mathrm{ha}^{-1}$, and the volume of irrigation applied throughout the crop cycle in $\mathrm{m}^{3} \mathrm{ha}^{-1}$.

The Lilliefors test, available in the StatTools version 6.0 (Palisade, 2015), at 5\% significance level, was used to verify the normality of the yield and of the irrigation water productivity. ANOVA was performed for results from each location using $R$ version 3.2.2 with a $5 \%$ level of significance. Mean differences were separated using Tukey test, at the 5\% level of significance using R version 3.2.2 (R Program, 2016).

If significant differences on yield between locations were observed, box-and-whisker plots were prepared in order to qualitatively compare the median yield and irrigation water productivity of the counties and also to evaluate the inter-annual variation of yield and of irrigation water productivity In the box-and-whisker plots, the lines at the center of the rectangles indicate the median. The upper and lower sides of the rectangles indicate the values for the percentiles $75 \%$ and $25 \%$, respectively. The difference between percentiles $75 \%$ and $25 \%$ defines the interquartile interval (IQR). The upper trace above the rectangles indicates the value of the variable studied, obtained by adding the value corresponding to the $75 \%$ percentile to 1.5 times the IQR. The lower trace below the rectangles indicates the value of the variable studied, obtained by subtracting 1.5 times the IQR from the value corresponding to percentile 25\%. Open circles, when present, indicate discrepancies, that is, outliers (Chambers et al. 1983).

\section{Results and discussion}

The preliminary scenarios of sowing dates simulated indicated that, in all counties, the most appropriate planting period is the month of February (Table 2) as also has been reported by Andrade et al. (2009) and Cardoso et al. (2004). According to these authors February is good for irrigated maize sowing since the daytime is sunny with high enough temperature to favor growth and development of maize but not too high to shorten the cycle duration, and the nighttime temperature is low preventing unnecessary maintenance respiration.

Table 2: Best sowing date for the six counties evaluated.

\begin{tabular}{cc}
\hline Location & Best Sowing Date \\
\hline Janauba & $20 /$ Feb \\
Lavras & $06 /$ Feb \\
Paracatu & $20 /$ Feb \\
Patos de Minas & $13 / F e b$ \\
Sete Lagoas & $20 / F e b$ \\
Uberaba & $13 / F e b$ \\
\hline
\end{tabular}

\section{A. Effect of irrigation on yield}

The simulations for conditions in Janauba, Paracatu and Sete Lagoas showed higher yields when irrigation was full (Figure 1). Yield from treatments 100, 105 and I10 in the county of Sete Lagoas surpassed all others with yield of $11,378 \mathrm{~kg} \mathrm{ha}^{-1}, 11,328 \mathrm{~kg} \mathrm{ha}^{-1}$ and $11,184 \mathrm{~kg} \mathrm{ha}^{-1}$, respectively. The smallest average yield of $8,912 \mathrm{~kg} \mathrm{ha}^{-1}, 8,829 \mathrm{~kg} \mathrm{ha}^{-1}, 8,064 \mathrm{~kg} \mathrm{ha}^{-1}, 7,701 \mathrm{~kg} \mathrm{ha}^{-1}, 7,298 \mathrm{~kg} \mathrm{ha}^{-1}$ and 6,859 $\mathrm{kg} \mathrm{ha}^{-1}$ were simulated in Janauba for the treatments I00, I05, I10, I15, 120 and I25, respectively. In Paracatu, the average yield of 10,064 $\mathrm{kg} \mathrm{ha}^{-1}, 9,616 \mathrm{~kg} \mathrm{ha}^{-1}$ and 9,401 $\mathrm{kg} \mathrm{ha}^{-1}$ was simulated for the scenario of full irrigation and of irrigation reduced 
by $5 \%$ and $10 \%$, respectively.

In Patos de Minas, the average yield was higher in treatments I15, I20, and I25, with average yield of 11,102 kg $\mathrm{ha}^{-1}, 10,946 \mathrm{~kg} \mathrm{ha}^{-1}$ and 10,727 kg ha ${ }^{-1}$, respectively. In Lavras, treatment with irrigation depth reduced by $15 \%$ (I15), produced an average yield higher than the treatments with $5 \%$ and 10\% deficit (I05 and I10), and 9,936 $\mathrm{kg} \mathrm{ha}^{-1}, 9,593 \mathrm{~kg} \mathrm{ha}^{-1}$ and 9,717 $\mathrm{kg} \mathrm{ha}^{-1}$, respectively (Figure 1).

On the other hand, in Uberaba yield remained stable for all deficit irrigation treatments (Figure 1), with an average yield of $10,634 \mathrm{~kg} \mathrm{ha}^{-1}, 10,628 \mathrm{~kg} \mathrm{ha}^{-1}, 10,624 \mathrm{~kg} \mathrm{ha}^{-1}, 10,597 \mathrm{~kg} \mathrm{ha}^{-1}, 10,550 \mathrm{~kg} \mathrm{ha}^{-1}$ and 10,499 kg $\mathrm{ha}^{-1}$, respectively, for the treatments $100,105,110,115,120$ and 125.

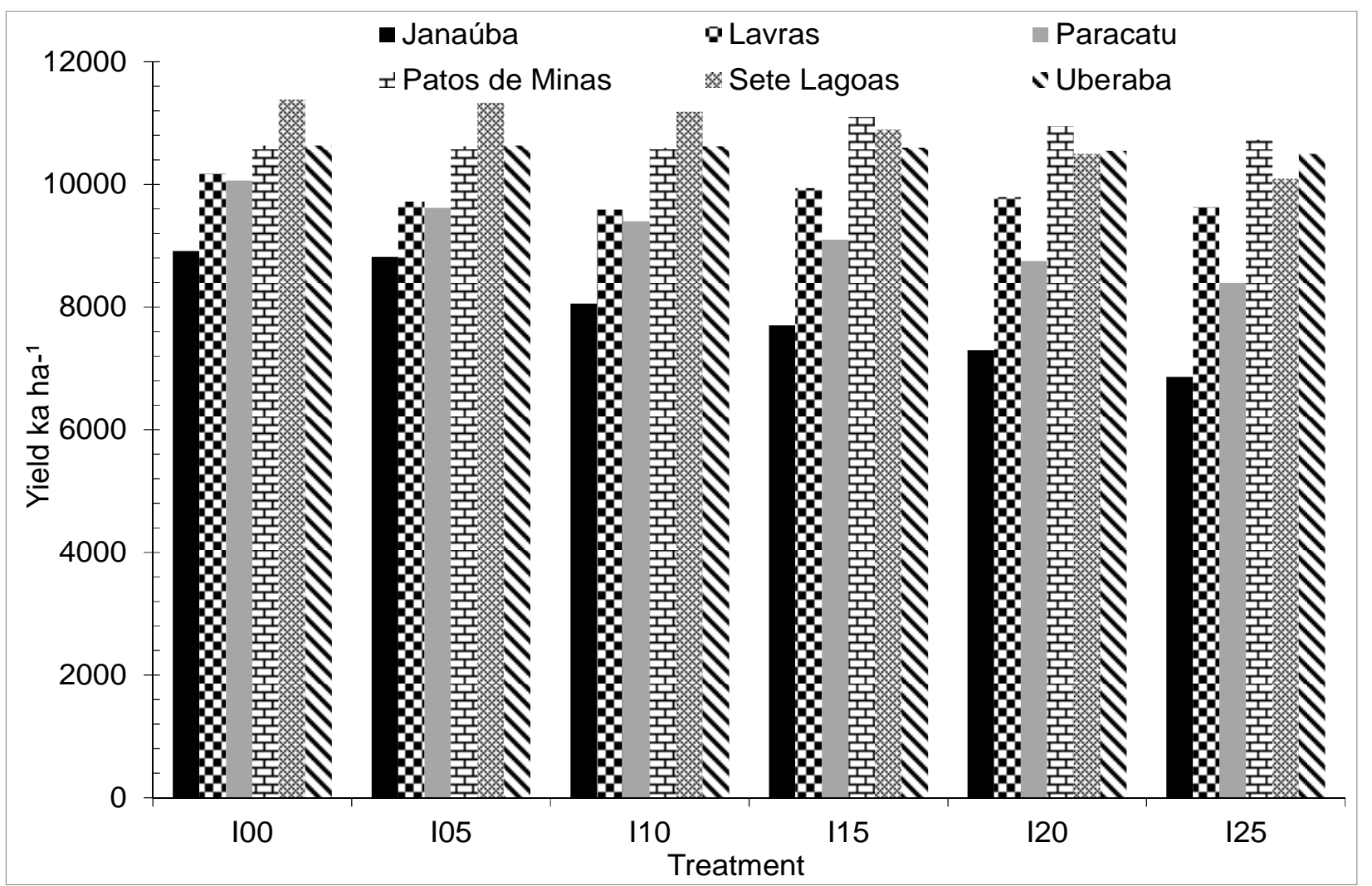

Figure 1: Simulated average yield of maize grown under different irrigation strategies in the state of Minas Gerais.

Significant differences on yield were found in Janauba, Paracatu and Sete Lagoas for the treatment 100, 105, $110,115, I 20$ and I25 while no yield differences were obtained in for the treatment I00, I05, I10, I15, I20 and I25 in Lavras, Patos de Minas and Uberaba (Table 3).

Table 3: Critical values of $F(A N O V A)$ for the significance level $(\alpha)$ of $5 \%$, relative to the yield values.

\begin{tabular}{cl}
\hline Source of Variation & $\operatorname{Pr}>\mathrm{Fc}^{(1)}$ \\
\hline Janauba & $0.0000^{*}$ \\
Lavras & $0.5618^{\text {ns }}$ \\
Paracatu & $0.0000^{*}$ \\
Patos de Minas & $0.2821^{\text {ns }}$ \\
Sete Lagoas & $0.0000^{*}$ \\
Uberaba & $0.9940^{\text {ns }}$ \\
\hline
\end{tabular}

(1) Values Pr> Fc equal to or less than 0.05 indicates a significant difference at $5 \%$ probability.

For conditions in Janauba, no significant difference was detected in the treatments 100 and 105, indicating that it could be used an irrigation depth $5 \%$ less than the full irrigation depth required by maize in that county (Table 4). This $5 \%$ reduction in the irrigation depth, corresponding to a reduction of $1.1 \%$ in the yield, resulted in an increase of $0.54 \%$ in the irrigation water productivity, which raised from $2.63 \mathrm{~kg} \mathrm{~m}^{-3}$ to $2.64 \mathrm{~kg} \mathrm{~m}^{-3}$. At the other end, a reduction of $25 \%$ in the average irrigation depth applied, caused $23 \%$ reduction in the yield and an 
increase of only $4.26 \%$ in the irrigation water productivity, which increased from $2.63 \mathrm{~kg} \mathrm{~m}^{-3}$ to $2.74 \mathrm{~kg} \mathrm{~m}^{-3}$. However, this is not a management strategy that would be recommended because it causes a considerable reduction in yield. The stress imposed to the crop, due to the deficit irrigation and to the low total soil water capacity (Table 4), was aggravated by the deleterious effect of high night air temperature of the region, causing a reduction in grain production. In Janauba it was observed the highest values of maximum and minimum air temperatures (Figure 2), which increase the gradient of the potential between the leaf and the air (Galon et al. 2010). According to Floss (2008) this situation increases the transpiration rate and, consequently, promotes greater water consumption, which may be the main limiting factor for maize production under high temperature conditions. Additionally, among all the counties studied, Janauba presented a soil with the lowest WHC. According to Letey (1985) the grain yield is affected by the water storage capacity of the soil, because this restriction may hinder the flow of water absorption by the plant.

Table 4: Tukey test at the level of significance $\alpha=5 \%$ for the average maize yield in Janauba, Paracatu and Sete Lagoas.

\begin{tabular}{|c|c|c|c|c|}
\hline \multirow[t]{2}{*}{ Location } & \multirow{2}{*}{$\frac{\text { Treatment }^{(1)}}{100}$} & \multicolumn{2}{|c|}{ Yield kg ha ${ }^{-1}$} & \multirow{2}{*}{$\frac{\text { Reduction }}{(2)}$} \\
\hline & & 8912 & $A$ & \\
\hline \multirow{5}{*}{ Janauba } & 105 & 8819 & A & $1,1 \%$ \\
\hline & 110 & 8054 & B & $9,6 \%$ \\
\hline & $\mid 15$ & 7701 & $\mathrm{BC}$ & $13,6 \%$ \\
\hline & 120 & 7298 & $C D$ & $18,1 \%$ \\
\hline & 125 & 6859 & $\mathrm{D}$ & $23,0 \%$ \\
\hline \multirow{6}{*}{ Paracatu } & 100 & 10064 & A & $0 \%$ \\
\hline & 105 & 9616 & $A B$ & $4.4 \%$ \\
\hline & 110 & 9401 & ABC & $6.5 \%$ \\
\hline & 115 & 9095 & $B C D$ & $9.6 \%$ \\
\hline & 120 & 8750 & $C D$ & $13.0 \%$ \\
\hline & 125 & 8397 & D & $16.5 \%$ \\
\hline \multirow{6}{*}{$\begin{array}{l}\text { Sete } \\
\text { Lagoas }\end{array}$} & 100 & 11378 & A & $0 \%$ \\
\hline & 105 & 11328 & A & $0.4 \%$ \\
\hline & 110 & 11184 & $A B$ & $1.7 \%$ \\
\hline & 115 & 10888 & $A B$ & $4.3 \%$ \\
\hline & 120 & 10496 & $\mathrm{BC}$ & $7.8 \%$ \\
\hline & 125 & 10090 & C & $11.3 \%$ \\
\hline
\end{tabular}

(1) $100,105,110,115,120$ and 125 corresponds to $0 \%, 5 \%, 10 \%, 15 \%, 20 \%$ and $25 \%$ reduction of full irrigation. Within location, means followed by the same letter are not significantly different at alpha $=5 \%$. ${ }^{(2)}$ Reduction in yield taking the full irrigation treatment (100) as the baseline.

For Paracatu the treatment with full irrigation resulted in an average yield of $10,063 \mathrm{~kg} \mathrm{ha}^{-1}$ (Table 4). There was no statistical difference between treatments 100,105 and 110 , although the reduction in grain yield between the treatment with full irrigation and that with a reduction of $5 \%$ and $10 \%$ of the irrigation depth, has been $4.4 \%$ and $6.5 \%$, respectively; the irrigation water productivity increased from $3.35 \mathrm{~kg} \mathrm{~m}^{-3}$ to $3.38 \mathrm{~kg} \mathrm{~m}^{-3}$ and to 3.49 $\mathrm{kg} \mathrm{m}^{-3}$, respectively. The reduction of the irrigation depth by $25 \%$ caused a $16.5 \%$ decrease in yield and an increase of $11.2 \%$ in irrigation water productivity, which raised from $3.35 \mathrm{~kg} \mathrm{~m}^{-3}$ to $3.78 \mathrm{~kg} \mathrm{~m}^{-3}$, corroborating the studies of Martins, (2012) which concluded that the adoption of deficit irrigation increases the water productivity, but reduces the yield of most crops. If the goal is to save water for maize production in Paracatu, with a small reduction in yield, the best alternative would be the use of irrigation with a deficit of $5 \%$ to $10 \%$.

The highest average yield, for all treatments, was obtained in Sete Lagoas (Table 4). The yield values were 
also more stable, since no statistically significant differences were observed between the average yield of the treatments $100,105,110$ and 115 . In this case, it can be allowed a reduction of up to $15 \%$ on the required irrigation depth, with a decrease of only $4.3 \%$ in the yield and an increase in the irrigation water productivity from $3.66 \mathrm{~kg} \mathrm{~m}^{-3}$ to $4.12 \mathrm{~kg} \mathrm{~m}^{-3}$. The smallest average yield was simulated for the treatments 120 and I25, with a reduction of $7.8 \%$ and $11.3 \%$, respectively, as compared to the treatment with full irrigation. The irrigation water productivity of the treatments I20 and I25 increased from $4.31 \mathrm{~kg} \mathrm{~m}^{-3}$ to $4.22 \mathrm{~kg} \mathrm{~m}^{-3}$, respectively, which corresponds to $13.3 \%$ and $15.1 \%$ increment, as compared to 100 . However, despite the increase in the irrigation water productivity for these treatments, water savings of $25 \%$ would not be a viable strategy as it would cause a significant reduction in the crop yield.
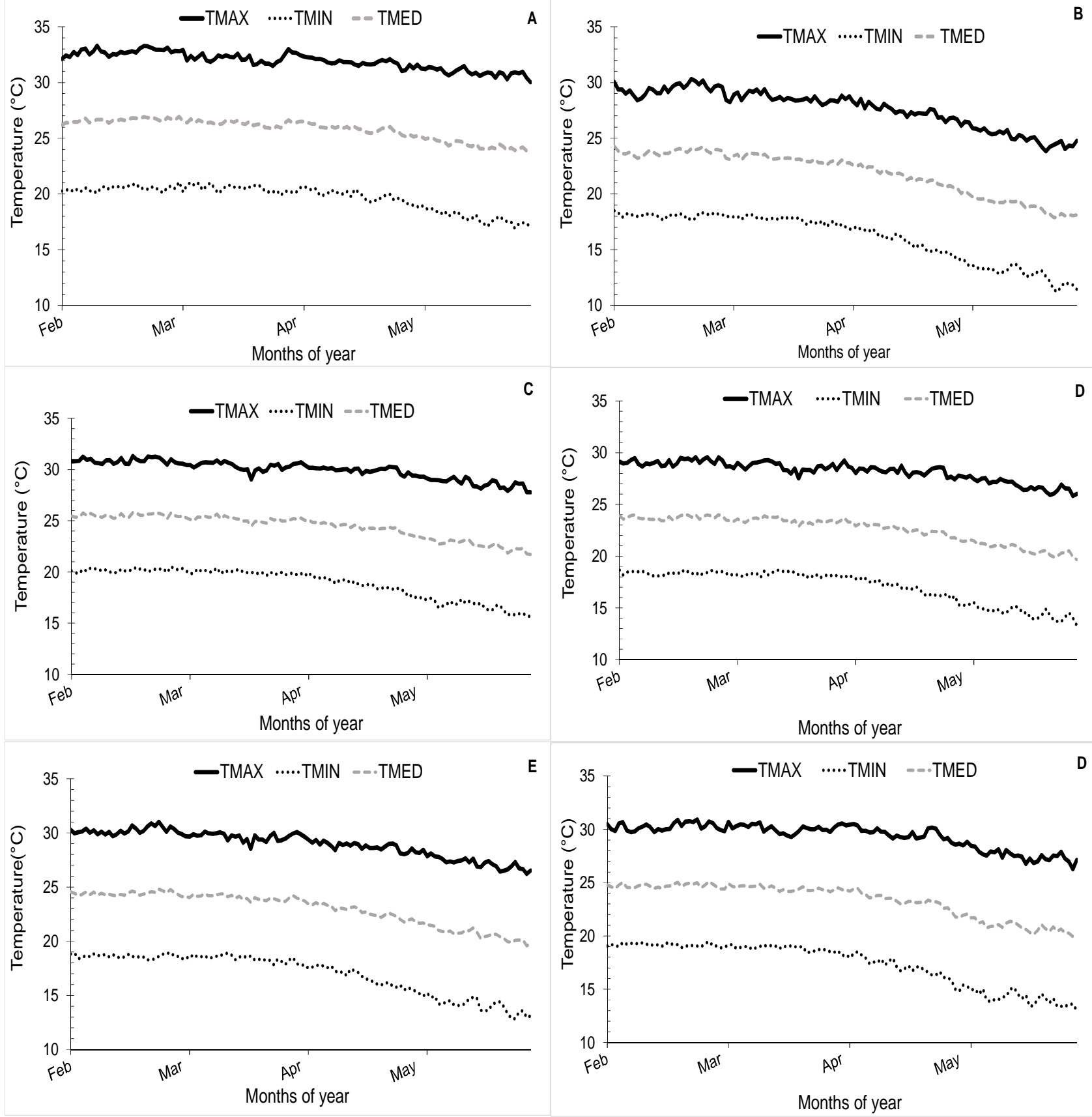

Figure 2. Average values of maximum, minimum and average temperature considering the 33 years of weather data for Janauba (A), Lavras (B), Patos de Minas (C), Paracatu (D), Sete Lagoas (E) and Uberaba (F). 

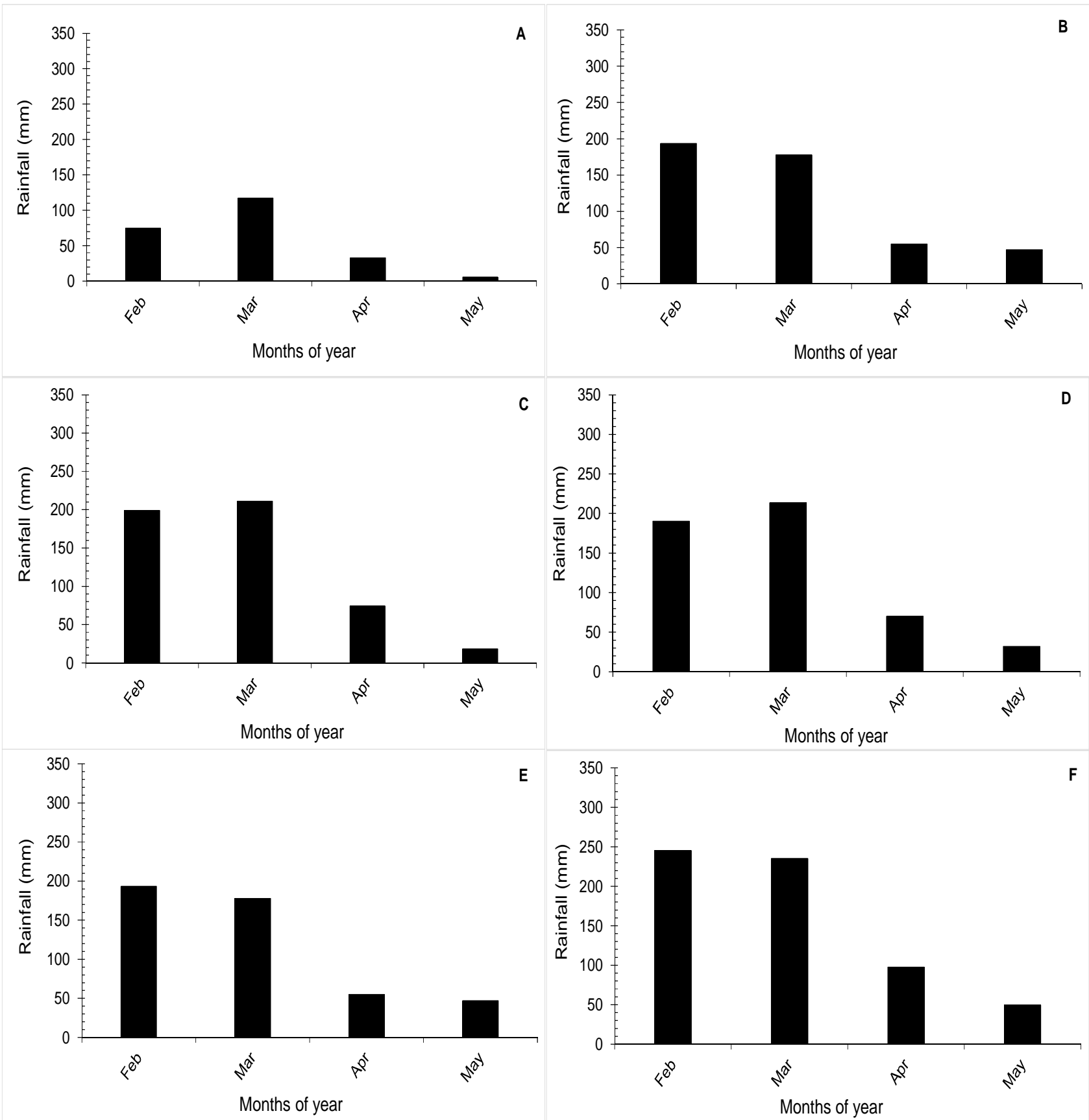

Figure 3. Average precipitation, considering the 33 years of weather data, for Janauba (A), Lavras (B), Patos de Minas (C), Paracatu (D), Sete Lagoas (E) and Uberaba (F).

When analyzing the frequency distribution data, we notice that for conditions in Janauba the water stress due to the use of deficit irrigation caused considerable inter-annual variation in the yield of all treatments, but especially in the treatments I10, I15, I20 and I25, for which the amplitude was higher (Figure 4A). Large interannual variability of simulated yield can occur even under full irrigation condition since other factors such as air temperature, besides water stress, can affect maize yield (Andrade et al. 2009).

In Paracatu the range between the minimum and maximum yield was greater than that observed in all treatments in Janauba, indicating greater inter-annual variability (Figure 4B). However, unlike Janauba, the inter-annual variability for conditions in Paracatu tended to be higher in the treatments which received higher irrigation depths. In some years, the combination of factors such as low night temperature, high solar radiation incidence and good soil-water water supply, may favor high yield. On the other hand, even under minimum water stress if those weather factors are not favorable, the crop produces less, generating higher amplitude between maximum and minimum yield values. Fancelli and Dourado Neto (2000) point out that the grain yield reduction under high night temperature condition can also be a consequence of reduction in the crop cycle. 
The inter-annual variability of the yield for conditions in Sete Lagoas was high, even for the treatment with full irrigation (Figure 4C). Since other factors, in addition to water stress, affect the crop performance, there may be years when adding deleterious effects greatly reduces grain yield and vice-versa. However, in terms of average yield, the crop response to reductions in the irrigation depths was minimum (Table 4). A lower outlier was observed in the treatment 110 indicating that, in some of the years, the crop was more strongly affected by the water stress. For the treatment 115 there was a higher outlier, showing that, for this treatment, the crop better supported the deficit irrigation (Figure 4C). Unlike Janauba, in Sete Lagoas the treatment with 10\% deficit irrigation caused the smallest amplitude between the maximum and minimum yield. 


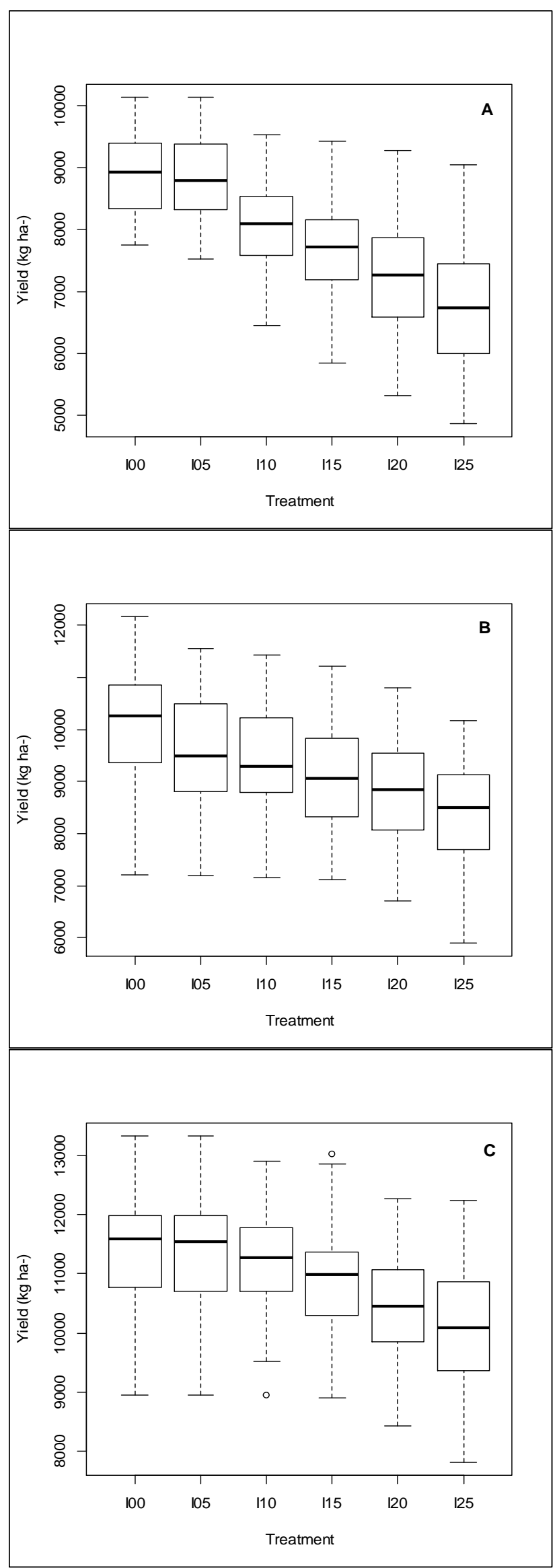


Figure 4: Box and whiskers of simulated yield for different treatments of deficit irrigation in Janauba (A), Paracatu (B) and Sete Lagoas (C).

The highest median yield, with greater production stability, was simulated for the treatment 100 in the counties of Janauba, Paracatu and Sete Lagoas. However, the treatment with $5 \%$ deficit in Janauba and Sete Lagoas, provided smaller inter-annual variation.

\section{B. Applied irrigation depths}

Janauba was the county that received the highest average depth of supplemental irrigation, which varied from $350 \mathrm{~mm}$, for the treatment with full irrigation, to $280 \mathrm{~mm}$, for the treatment with $25 \%$ deficit (Figure 5), promoting a decrease in the yield from $8.912 \mathrm{~kg} \mathrm{ha}^{-1}$ to $6.859 \mathrm{~kg} \mathrm{ha}^{-1}$ (Figure 1). Higher cumulated irrigation depths in Janauba is attributable to the lower average rainfall depth, of $231 \mathrm{~mm}$, registered along the crop cycle (Figure 3), associated with the smaller SWH capacity in this county (Table 1). According to Fiorin et al. (1997), there is a direct relationship between the SWH capacity and the yield of maize. These authors have shown that a soil with a high amount of water stored, positively correlates with high aboveground biomass and grain production.

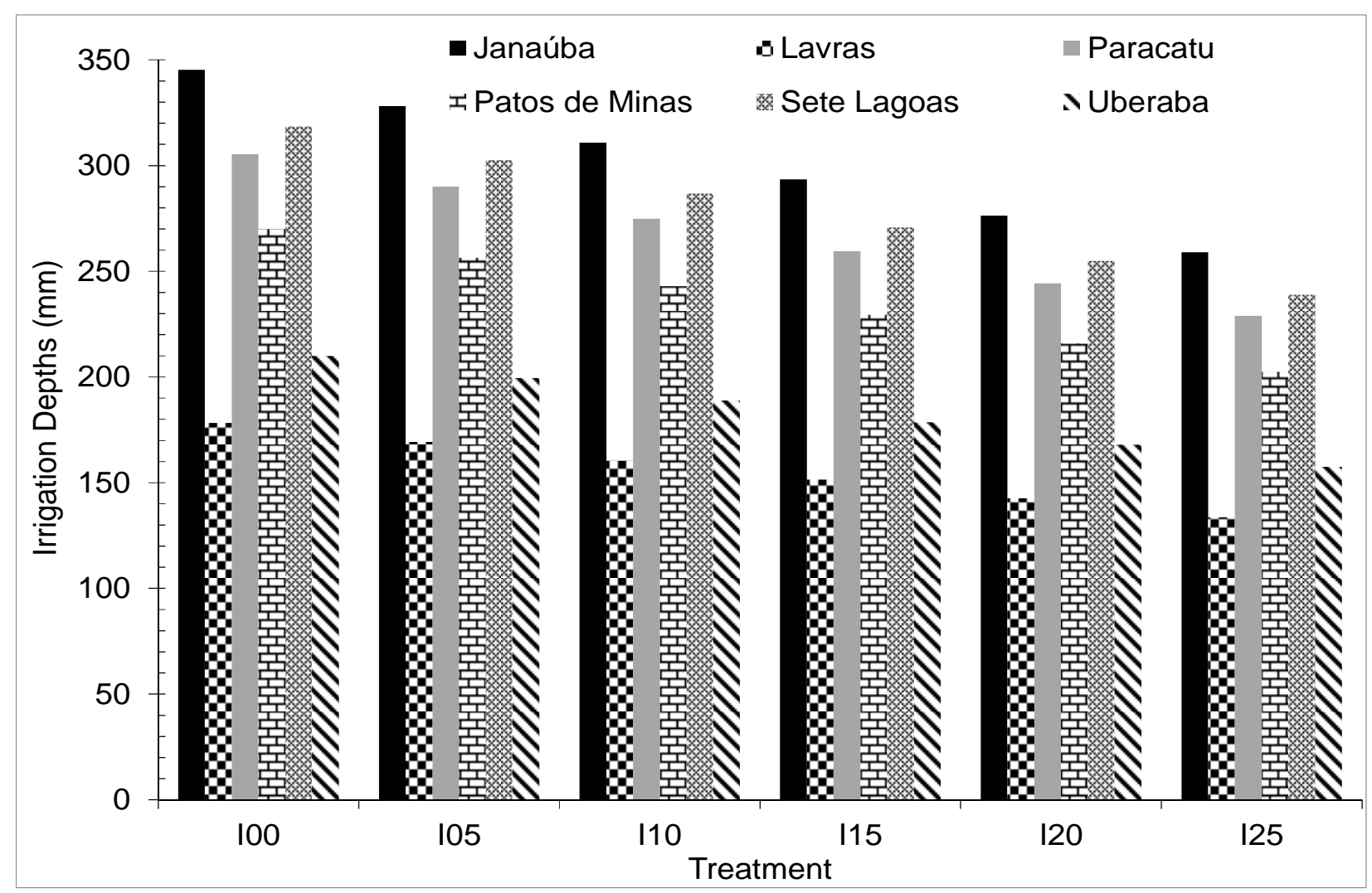

Figure 5: Irrigation depths required by the maize crop, for different levels of reduction in the full irrigation depths for the counties of Janauba, Lavras, Paracatu, Patos de Minas, Sete Lagoas and Uberaba.

In Lavras, as compared to Janauba, a higher cumulated depth of rainfall during the maize cycle, totaling 473 $\mathrm{mm}$, was recorded (Figure 3). This greater amount of rainfall resulted in lower average irrigation depths applied, which varied from $178 \mathrm{~mm}$, in the treatment with full irrigation, to $134 \mathrm{~mm}$, in the treatment, with $25 \%$ deficit (Figure 5). The higher average rainfall depth occurred during the crop cycle attenuated the possible deleterious effect of the deficit irrigation on the yield, which reduced from $10.175 \mathrm{~kg} \mathrm{ha}^{-1}$ to $9.627 \mathrm{~kg} \mathrm{ha}^{-1}$, a drop of only $5.39 \%$ (Figure 1 ).

In Uberaba, $210 \mathrm{~mm}$ were applied on the treatment with full irrigation and $158 \mathrm{~mm}$ on that with $25 \%$ deficit (Figure 5). The savings of $25 \%$ in the irrigation depth caused little effect on the maize average yield, which dropped from $10.634 \mathrm{~kg} \mathrm{ha}^{-1}$ to $10.499 \mathrm{~kg} \mathrm{ha}^{-1}$, resulting in a decrease of only $1.27 \%$ (Figure 1 ). This yield stability can be attributed to the cumulated precipitation of $628 \mathrm{~mm}$, well distributed during the crop cycle (Figure 3), and to the higher SWH capacity in Uberaba. According Boggione et al. (2014) the low depth of full irrigation during the maize cycle in Uberaba is attributed to the higher SWH capacity, as compared to other locations with similar rainfall pattern. 
In the county of Patos de Minas, the irrigation depths ranged from $270 \mathrm{~mm}$, for the treatment with full irrigation, to $202 \mathrm{~mm}$, for the treatment with $25 \%$ deficit (Figure 7A). Unlike the other counties, in Patos de Minas a reduction of $25 \%$ in the irrigation depth slightly increased the yield from $10.633 \mathrm{~kg} \mathrm{ha}^{-1}$ to $10.727 \mathrm{~kg} \mathrm{ha}^{-1}$, or a $0.88 \%$ raise. This can be due to the $506 \mathrm{~mm}$ rainfall depth, well distributed along the maize cycle. As in the county of Patos de Minas, in Uberaba the largest rainfall depth of $628 \mathrm{~mm}$, well distributed throughout the crop cycle (Figure 3), minimized the effects of the the use of deficit irrigation on maize.

The irrigation depths applied throughout the maize cycle, for all treatments, were similar in Sete Lagoas and Paracatu. Depths of $319 \mathrm{~mm}$ and $305 \mathrm{~mm}$ were applied in the full irrigation treatment in Sete Lagoas and Paracatu, respectively, while for the treatment with $25 \%$ deficit, it was applied $239 \mathrm{~mm}$ and $229 \mathrm{~mm}$, respectively (Figure 5). However, a reduction of the irrigation depth by $25 \%$ in Paracatu penalized more strongly the crop yield since it reduced $16.5 \%$, against $11.3 \%$ reduction in Sete Lagoas. In Paracatu the SWH capacity in the layer $0.5 \mathrm{~m}$ of the soil profile is $55.5 \mathrm{~mm}$, while in Sete Lagoas the SWH capacity is $62.5 \mathrm{~mm}$, which makes the deficit irrigation in this county a little less stressful. Another reason would be associated to the climate elements, such as the air temperature, which can affect the maize crop cycle and, ultimately, the yield. In Paracatu, it was observed average maximum and minimum temperatures higher than in Sete Lagoas (Figure 2). The day and nighttime temperature rise contributes to the reduction of net photosynthetic rate, due to increased respiration and to the shorter maize cycle, directly reducing in the yield (Fancelli \& Dourado Neto, 2000).

\section{Water Productivity}

As expected, the use of deficit irrigation in maize led to an increase in the irrigation water productivity in all counties (Figure 6). According to Souza et al. (2015), this occurs because there is an inversely proportional relation between irrigation depth and the water productivity based on irrigation depth. A negative linear effect of greater irrigation depths in the water use efficiency was observed by Brito et al. (2013) working with sweet corn in Pombal, PB, Brazil.

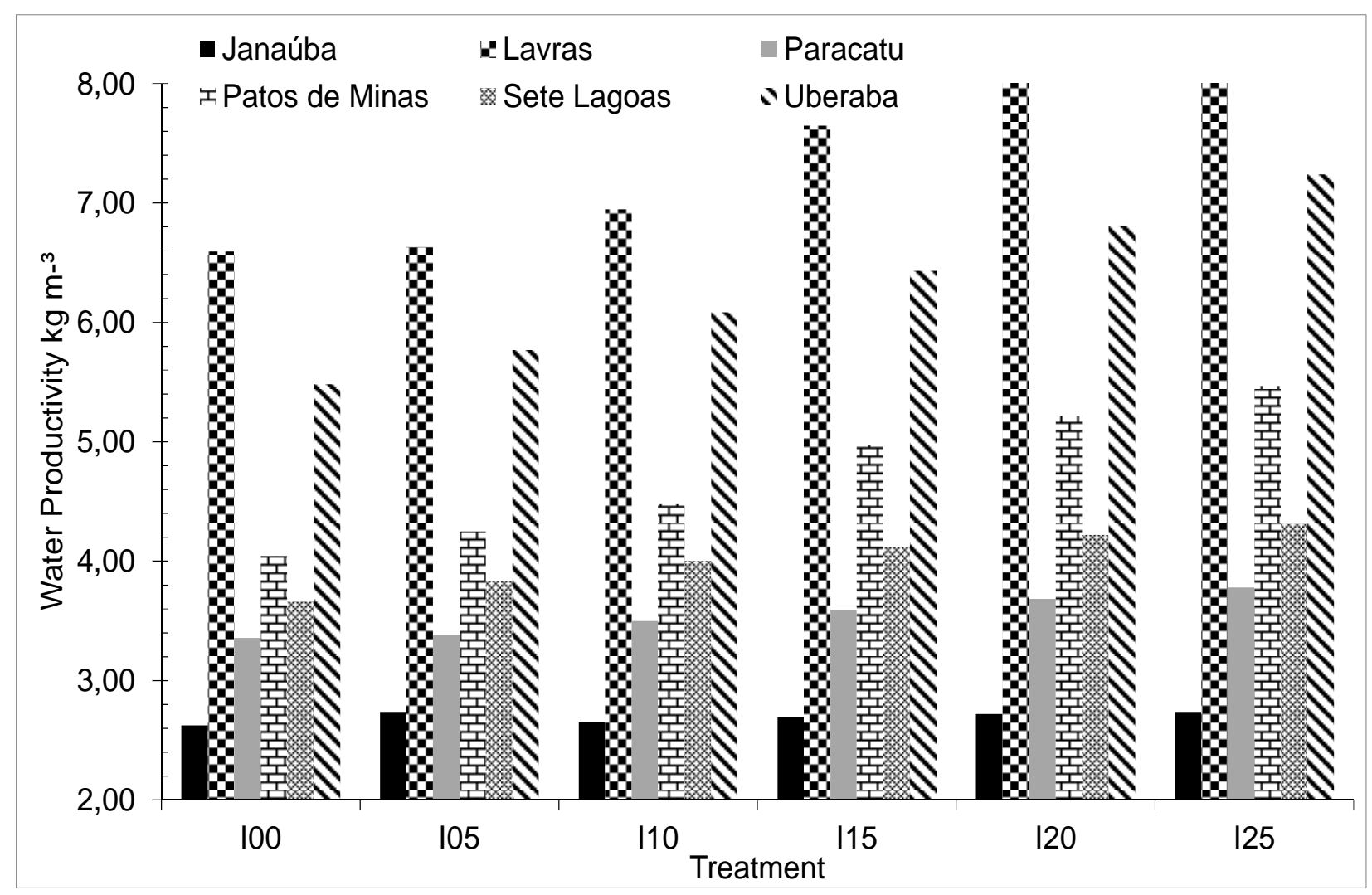

Figure 6: Average water productivity, based on irrigation depth, simulated for the counties of Janauba, Lavras, Paracatu, Patos de Minas, Sete Lagoas and Uberaba, for different irrigation depths applied to the maize crop.

Janauba presented the lowest average values of water productivity for all irrigation management treatments. The full irrigation treatment provided a irrigation water productivity of $2.63 \mathrm{~kg} \mathrm{~m}^{-3}$, while the treatment with $25 \%$ deficit increased the irrigation water productivity to $2.74 \mathrm{~kg} \mathrm{~m}^{-3}$ (Figure 6), corresponding to $4.26 \%$ rise. 
Boggione et al. (2014), in their studies reported higher a water productivity based on irrigation of $4.1 \mathrm{~kg} \mathrm{~m}^{-3}$ for Janauba..

In Sete Lagoas, the maize irrigation water productivity was $3.66 \mathrm{~kg} \mathrm{~m}^{-3}$, for the treatment with full irrigation, and $4.31 \mathrm{~kg} \mathrm{~m}^{-3}$, for the treatment with $25 \%$ deficit, an increase of $15.1 \%$ (Figure 6). In Paracatu, the maize crop presented an increase of $11.2 \%$ in the irrigation water productivity, rising from $3.36 \mathrm{~kg} \mathrm{~m}^{-3}$ to $3.78 \mathrm{~kg} \mathrm{~m}^{-3}$, when subjected to a $25 \%$ irrigation deficit. Higher values of irrigation water productivity were observed in Patos de Minas, Uberaba and Lavras. In Uberaba we observed the largest average values of irrigation water productivity, which ranged from $5.48 \mathrm{~kg} \mathrm{~m}^{-3}$ to $7.23 \mathrm{~kg} \mathrm{~m}^{-3}$, for treatment 100 and 125 , respectively (Figure 6), corresponding to a $24.3 \%$ increase. In Lavras, the irrigation water productivity ranged from $6.58 \mathrm{~kg} \mathrm{~m}^{-3}$, for the treatment with full irrigation, to $8.49 \mathrm{~kg} \mathrm{~m}^{-3}$, for the treatment with $25 \%$ deficit irrigation, resulting in an increase of $22.3 \%$. As in Uberaba and Lavras, in the county of Patos de Minas the irrigation water productivity showed a linear response to the reduction on the irrigation depth, starting with $4.04 \mathrm{~kg} \mathrm{~m}^{-3}$, for the treatment with full irrigation, and reaching $5.47 \mathrm{~kg} \mathrm{~m}^{-3}$, for the treatment with $25 \%$ deficit, resulting in a rise of $26.1 \%$ (Figure 6). Considering the water productivity, based on irrigation, for maize, Payero et al. (2009) reported values of $6.5 \mathrm{~kg}$ $\mathrm{m}^{-3}$ to $8.64 \mathrm{~kg} \mathrm{~m}^{-3}$, which are close to the average values found in our study.

For the counties of Patos de Minas, Sete Lagoas and Uberaba we observed statistically significant differences between the average irrigation water productivity values for the treatments 100, 105, 110, 115, I20 and I25 of deficit irrigation (Table 5).

Table 5: Critical $F$ values (ANOVA) at a significance level ( $\alpha$ ) equal to $5 \%$ for irrigation water productivity.

\begin{tabular}{cl}
\hline Source of Variation & $\mathrm{Pr}>\mathrm{Fc}^{(1)}$ \\
\hline Janaúba & $0.9479^{\text {ns }}$ \\
Lavras & $0.1838^{\text {ns }}$ \\
Paracatu & $0.0661^{\text {ns }}$ \\
Patos de Minas & $0.0000^{*}$ \\
Sete Lagoas & $0.0043^{*}$ \\
Uberaba & $0.0029^{*}$ \\
\hline
\end{tabular}

${ }^{(1)}$ Values $\mathrm{Pr}>\mathrm{Fc}$ equal to or less than 0.05 indicates a significant difference at $5 \%$ probability.

When applying the Tukey test to the average irrigation water productivity for Patos de Minas, with $5 \%$ significance level, we observed that the highest values was obtained for the treatment with $25 \%$ deficit and the lowest was simulated for the treatment with full irrigation, resulting in a reduction of $26.1 \%$ (Table 6 ). The treatment with $25 \%$ irrigation deficit also provided an increase of $0.88 \%$ in the yield and, along with the treatments $\mathrm{I} 20$ and 115 , can be considered as a management strategy for water savings in that county. There was no significant difference between the irrigation water productivity for treatments 125,120 and I15, between $\mathrm{I} 15$ and I10 and between I10, 105 and 100 . The well distributed rainfall depth of $506 \mathrm{~mm}$ during the crop cycle (Figure 3), contributed to the stability of the yield and of the irrigation water productivity, even when the crop was subjected to a strong irrigation deficit.

In Sete Lagoas, the irrigation water productivity of treatments I25, I20, I15, 110 and 105 did not differ from each other statistically, at a level of $5 \%$ of significance. As well as, the treatments 115, 110, 105 and 100 also did not differ from each other statistically (Table 6 ). The irrigation water productivity for the full irrigation treatment decreased from $4.31 \mathrm{~kg} \mathrm{~m}^{-3}$ to $3.66 \mathrm{~kg} \mathrm{~m}^{-3}$, which corresponds to a $15.1 \%$ reduction, as compared to the treatment with an irrigation deficit of $25 \%$. Despite the treatment 125 had shown the highest irrigation water productivity, a drop of $11.3 \%$ in the maize yield was observed. A reduction of up to $15 \%$ in the irrigation depth, as compared to the full irrigation, reduced the irrigation water productivity by $4.5 \%$ and would be tolerable for the maize production in Sete Lagoas.

In Uberaba, as in other counties, the irrigation water productivity increased with the reduction in the irrigation depth applied (Table 6). As compared to the other municipalities, Uberaba showed the highest average values for irrigation water productivity in all treatments. Given the higher and well distributed rainfall depth of $628 \mathrm{~mm}$ recorded for Uberaba (Figure 3), the maize crop showed greater stability in the grain production, even when receiving irrigation depths smaller than the full, providing higher irrigation water productivities. Furthermore, Uberaba presented the higher SWH capacity, which positively influenced the irrigation water productivity. The major differences in irrigation water productivity were observed between the treatments 125 and 100 , with a reduction of $24.3 \%$. There was no statistical difference between the average irrigation water productivity for the treatments $120,115,110,105$ and 100 . The irrigation deficit of $20 \%, 15 \%, 10 \%$ and $5 \%$ reduced yield by only $0.79 \%, 0.35 \%, 0.9 \%$ and $0.05 \%$, respectively. Thus, it can be said that, in Uberaba, the maize crop has the potential to be irrigated with an average reduction of the irrigation depth of up to $20 \%$. 
According to Mi et al. (2012), the amount of precipitation may affect the water productivity of maize. In their work carried out in Northeastern China they found that in dry years the water productivity was low and in wet years, when the annual rainfall averages $500 \mathrm{~mm}$, the water productivity reached maximum values.

Table 6: Tukey test at the level of significance $\alpha=5 \%$ for average irrigation water productivity for the maize crop in Patos de Minas.

\begin{tabular}{|c|c|c|c|c|}
\hline Location & Treatment $^{(1)}$ & \multicolumn{2}{|c|}{ Water Productivity $\left(\mathrm{kg} \mathrm{m}^{-3}\right)$} & Reduction ${ }^{(2)}$ \\
\hline \multirow{6}{*}{ Patos de Minas } & 125 & 5,47 & $A$ & $0.0 \%$ \\
\hline & 120 & 5,22 & $A$ & $4.6 \%$ \\
\hline & 115 & 4,97 & $A B$ & $9,10 \%$ \\
\hline & 110 & 4,48 & $\mathrm{BC}$ & $18.1 \%$ \\
\hline & 105 & 4,25 & $\mathrm{C}$ & $22.3 \%$ \\
\hline & 100 & 4,04 & $\mathrm{C}$ & $26.1 \%$ \\
\hline \multirow{6}{*}{ Sete Lagoas } & 125 & 4.31 & A & $0.0 \%$ \\
\hline & 120 & 4.22 & $A$ & $2.2 \%$ \\
\hline & 115 & 4.12 & $A B$ & $4.6 \%$ \\
\hline & 110 & 4.00 & $A B$ & $7,20 \%$ \\
\hline & 105 & 3.84 & $A B$ & $11.1 \%$ \\
\hline & 100 & 3.66 & $\mathrm{~B}$ & $15.1 \%$ \\
\hline \multirow{6}{*}{ Uberaba } & 125 & 7.23 & A & $0 \%$ \\
\hline & 120 & 6.81 & $A B$ & $5.9 \%$ \\
\hline & 115 & 6.43 & $A B$ & $11.1 \%$ \\
\hline & 110 & 6.08 & $A B$ & $15.9 \%$ \\
\hline & 105 & 5.76 & $B$ & $20.3 \%$ \\
\hline & 100 & 5.48 & $\mathrm{~B}$ & $24.3 \%$ \\
\hline
\end{tabular}

(1) $100,105,110,115,120$ and 125 corresponds to $0 \%, 5 \%, 10 \%, 15 \%, 20 \%$ and $25 \%$ reduction in irrigation depth. Means followed by the same letter do not differ by Tukey test at $5 \%$. ${ }^{(2)}$ Reduction in the water productivity taking the full irrigation treatment (I00) as the baseline.

A considerable inter-annual variation in the irrigation water productivity were noticed in all treatments in Patos de Minas (Figure 7A). The higher the deficit in the irrigation applied, the greater the variability of the water productivity since the crop has become more dependent on the prevailing rainfall conditions and on the SWH capacity in the rooting zone. Treatments $100,105,110$ and 115 showed a smaller amplitude in the irrigation water productivity, as compared to the treatments I20 and I25. In the treatment I15, an upper outlier was observed, indicating that, for this treatment, the maize crop has the potential to be irrigated with deficit without affecting the irrigation water productivity.

Analyzing the frequency distribution data of irrigation water productivity for Sete Lagoas (Figure 7B), it is observed that the inter-annual variability among all treatments was small. The smallest amplitude was obtained for the treatment I10, which showed two upper outliers. The treatments 105, I10, I15, I20 and I25 also showed upper outliers indicating that, even with the reduction of the irrigation depth, in some years, the irrigation water productivity was higher.

In Uberaba the inter-annual variability of the irrigation water productivity increased as more irrigation deficit was imposed to the crop (Figure 7C). In all treatments we observed upper outliers, indicating a differentiated crop response to deficit irrigation in some of the years. This is due to the higher SWH capacity in the rooting zone (Table 1), associated with the higher rainfall depths cumulated during the crop cycle, which could support the grain production even with lower irrigation depths being applied, leading to higher irrigation water productivity. According to Andrade et al. (2009) the amplitude in water productivity values is greater in treatments with 
deficit irrigation due to the strong effect of water stress on the maize crop reducing drastically the yield. Maximum median values of simulated water productivity, of about $2.10 \mathrm{~kg} \mathrm{~m}^{-3}$, were reported in their work, which is lower than median values simulated for all water deficit treatments for the municipalities of Patos de Minas, Sete Lagoas. 


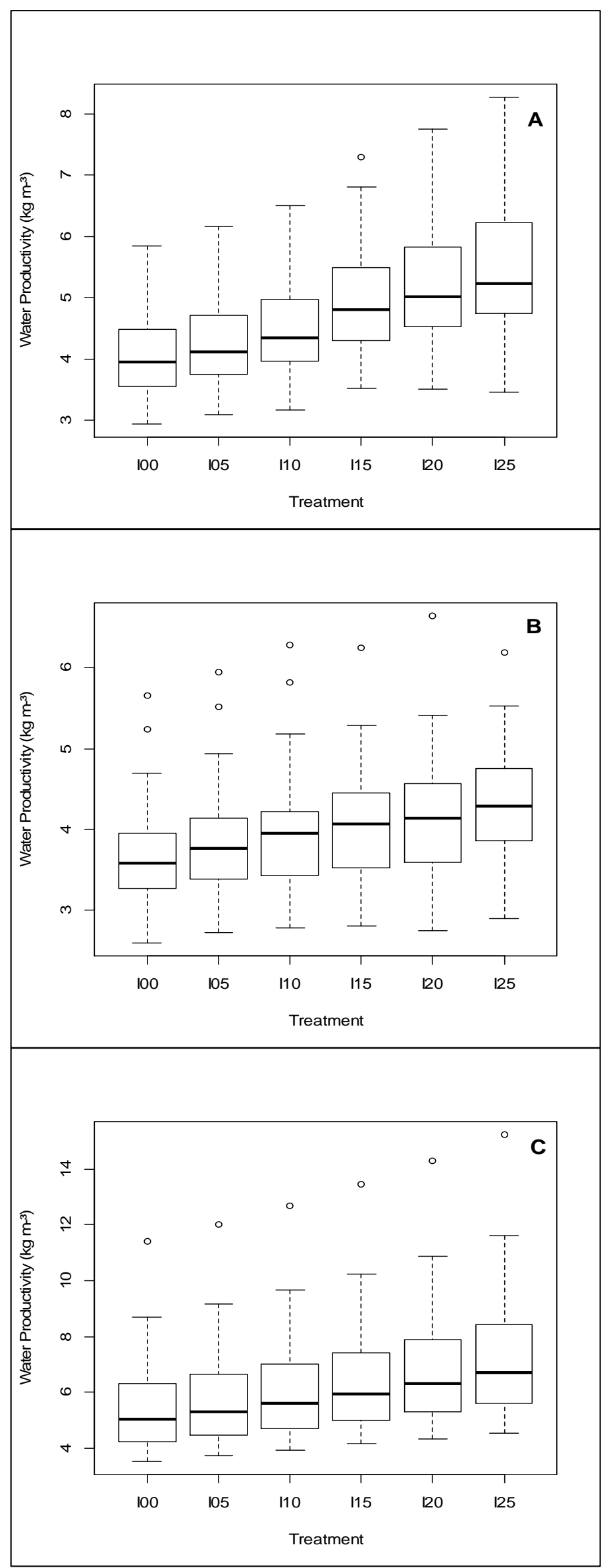


Figure 7: Box and whiskers plots for the simulated maize irrigation water productivity for different treatments of deficit irrigation in Patos de Minas (A), Sete Lagoas (B) and Uberaba (C).

\section{Conclusions}

The maize response to water was different for each county studied. Significant differences in the average yield were observed in Janauba, Paracatu and Sete Lagoas. Significant differences in irrigation water productivity were found in Patos de Minas, Sete Lagoas and Uberaba.

In Janauba and Paracatu maize has the potential to be irrigated with a deficit of up to $5 \%$ and $10 \%$, respectively, while for Sete Lagoas and Lavras reduction on irrigation depths can be as much as $15 \%$ of the maximum required depth, while in Uberaba and Patos de Minas irrigation reduction can be as much as $25 \%$ of maximum water requirements.

The higher the irrigation deficit imposed to the maize crop, the higher the irrigation water productivity.

Irrespective of the deficit irrigation applied, Lavras presented the highest irrigation water productivity, followed by Uberaba and Patos de Minas.

\section{References}

Albuquerque, J. A., Fiorin, J. E., Reinert, D. J., Mutt, L. S., \& Silva, E. P. (1992). Spatial variability of soil properties and corn production. Santa Maria, Rio Grande Do Sul, Brasil.

Allen, R. G., Pereira, L. .., Raes, D., \& Smith, M. (1998). Crop evapotranspiration: guidelines for computing crop water requirements. Rome, Italy.

Andrade, C. L., Alvarenga, R. C., Albuquerque, P. E., Coelho, A. M., \& Teixeira, E. G. (2004). Water and solute dynamics in a latosol cultivated with irrigated maize: 1- percolation and water productivity. Porto Alegre, Rio Grande do Sul, Brazil.

Andrade, C. L., Amaral, T. A., Borges Júnior, J. C., Heinemann, A. B., Garcia, A. G., Tojo-Soler, C. M., et al. (2009). Growth modeling cultures: Applications to maize crop. Sete Lagoas, Brazil.

Andrade, C. L., Amaral, T. V., Silva, D. F., Gargia, A., Hoogenboom, G., Brito, R. A., et al. (2009). CERES-MAIZE model use as a tool in the definition of corn planting strategies: 3- Application and Water Productivity. Belo Horizonte, Minas Gerais, Brazil.

Angstrom, A. (1924). Solar and terrestrial radiation.

Bergamaschi, H., Dalmago, G. A., Bergonci, I., J., Bianchi, C. A., Muller, A. G., et al. (2004). Water distribution in the critical period of maize and grain production.

Boggione, I. M., Borges Júnuior, J. C., Andrade, C. L., Passion, J. S., \& Souza, P. G. (2014). Estimated productivity of water for irrigated corn in Minas Gerais. Jaboticabal, São Paulo, Brazil.

Brito, M. E., Araújo Som, G. D., Wanderley, J. A., Melo, A. S., Costa, F. B., \& Ferreira, M. G. (2013). Growth physiology and production of sweet corn under water stress.

Cardoso, O. C., Faria, R. T., \& Folegatti, M. V. (2004). Simulation of yield and climate scratchs for the off-season maize in Londrina-PR, using the model ceres-maize. Magazine Agricultural Engineering, 291-300.

Castro, C. R., \& Garcia, E. (1996). Competition between plants with emphasis on light feature. Rural Science, 167-174.

Chambers, J. M., Cleveland, W. S., Kleiner, B., \& Tukey, P. (1983). Graphical Methods for Data Analysis.

Conab. (s.d.). National Supply Company. Acesso em 22 de September de 2015, disponível em http://www.conab.gov.br

English, M. (1990). Deficit irrigation. I. Analytical framework. Journal of Irrigation and Drainage Engineering, 399-412. 
Fancelli, A. L., \& Golden Neto, D. (2000). Corn production.

FAO. (s.d.). Food and Agriculture Organization. Acesso em 15 de Agust de 2015, disponível em http://www.fao.org/nr/water/infores_databases_cropwat.html

Fiorim, J. E. (1997). Water storage in the soil and growth and yield of corn. Brazilian Magazine of Soil Science., 249-255.

Floss, E. L. (2007). Physiology programming using optimization. Magazine Brasilian of Irrigated Agriculture, 24-49.

Galon, L., Tironi, S. P., Rocha, A., Concenço, G., \& Alberto, C. (2010). Influence of abiotic factors on yield of maize. Magazine Tropica- Agricultural Sciences and Biologic., 18-38.

Geerts, S., \& Raes, D. (2009). Deficit irrigation as on-farm strategy to maximize crop water productivity in dry areas. Agricultural Water Management, 1275-1284.

Jones, C. A., \& Kiniry, J. R. (1986). CERES-MAIZE: A Simulation Model for Maize Growth and Development.

Jones, J. W., Hoogenboom, G., Porter, C. H., Boote, K. J., Batchelor, W. D., Hunt, L. A., et al. (2003). DSSAT cropping system model. European Journal of Agronomy, 235-265.

Kang, S., Shi, W., \& Zhang, J. (2000). An improved water-use efficiency for maize grown under regulated deficit irrigation.

Kirda, C. (202). Deficit irrigation scheduling based on plant growth stages showing water stress tolerance.

Letey, J. (19985). Relationship between soil physical properties and crop production.

Lima, S. C., Frizzone, J. A., Mateos, L., \& Fernandez, M. S. (2012). Water productivity estimate in a irrigated area in southem Spain. Magazine of Irrigated Agriculture., 51-60.

Martins, J. D., Carlesso D'aires, N., C., C. J., Dubou, V., \& Fries, H. (2012). Deficit irrigation to increase water use efficiency in the production of silage maize. Fortaleza, Ceará, Brazil.

Molden, D., Rust, H. M., Sakthivadivel, R., \& Makin, L. (2003). A water productivity Framework for Understanding and Action.

N., M., Zhang, Y. S., Ji, R. P., Cai, F., Zhang, S. J., \& Zhao, X. L. (2012). Effects of climate change on water use efficiency in rain-fed plants. International Journal of Plant Production.

Nied, A. H., Estefanel, V., Estefanel, V., Silva, J. C., \& Alberto, E. M. (2005). Maize sowing dates with lower risk of water shortage in the city of Santa Maria. Rural Science, 995-1002.

PALISADE. (s.d.). Acesso em 28 de November de 2015, disponível em http://www.palisade.com/stattols/

Payero, J. O., Tarkalson, D. D., Irmak, S., Davison, D., \& Petersen, J. L. (2009). Effect of timing of a deficit-irrigation allocation on corn evapotranspiration yield, water use efficiency and dry mass. Agricultural Water Management, 1387-1397.

Prescott, J. A. (1940). Evaporation from a water surface in relation to solar radiation. Transactions Royal Society of South Australia, 114-118.

R., P. (s.d.). Acesso em April de 29 de 2016, disponível em http://www.r-project.org/

Shioga, P. S., Oliveira, E. L., \& Gerage, A. C. (2004). Plant density and nitrogen fertilization in maize grow in the off season. Brazilian Magazine of Maize e Sorghum., 381-390.

Tsuji, G. Y., Uehara, G., \& Balas, S. (1994). DSSAT. version 3. International Benchmark Sites Network for Agrotechnology Transfer. 
Wagner, M. V., Jadoski, S., Maggi, M. F., Saito, L. R., \& Lima, A. S. (2013). Corn productivity estimate in function on water availabity in Guarapuava, PR, Brazil. Brazilian Magazine of Agricultural Engineering and Ambient., 170-179. 